RASĀYAN J. Chem.

Vol. 14 | No. 2 |1006-1010| April - June | 2021

ISSN: 0974-1496 | e-ISSN: 0976-0083 | CODEN: RJCABP

http://www.rasayanjournal.com

http://www.rasayanjournal.co.in

\title{
NANO-HYDROXYAPATITE AND ITS COMPOUNDS AND THEIR POTENTIAL IN THE FIGHT AGAINST COVID-19: A REVIEW
}

\author{
A. R. Noviyanti ${ }^{\varpi}$, D. R. Eddy, Rukiah and Y. Deawati \\ Physic and Inorganic Laboratory, Mathematics and Natural Sciences, Universitas Padjadjaran \\ J1. Raya Bandung-Sumedang Km. 21 Jatinangor, West Java, Indonesia 45363 \\ ${ }^{\square}$ Corresponding Author: atiek.noviyanti@unpad.ac.id
}

\begin{abstract}
Handling of the 2019 coronavirus disease (COVID-19) is still ongoing, both prevention, treatment, and care for sufferers. Therefore, the assessment of the antiviral material at these stages is a very important rapid response, including those from nanomaterials. Here, we have reviewed the potential of nano-hydroxyapatite and its compounds which are known to be antiviral and antibacterial for potential use in biomedical tools. Although clinical trials to assess the efficacy of this material needs to be conducted, this review highlighting important information, including an analysis of the potential as a delivery drug, antibacterial coating, and detection tools to fight the COVID-19 pandemic. Keywords: Antibacterial, Antiviral, Biomedical, Covid-19, Nano-hydroxyapatite (n-HA).
\end{abstract}

RASĀYAN J. Chem., Vol. 14, No.2, 2021

\section{INTRODUCTION}

Features around the world these final few months have been filled with references to Covid-19, the sickness coming about from contamination with a strain of coronavirus. The pathogen behind COVID-19, a new form of pneumonia ${ }^{1}$, is the 2019 novel coronavirus (2019-nCoV), also known as SARS-CoV-21 and HCoV19. For several of the infections covered, close contact with infected people is the most common mode of transmission. Person-to-person touch and an introduction are recognized as important transmission routes for SARS-CoV-2 (the infection that triggers Covid-19). Most patients have a great forecast, although a few turn out to be fundamentally sick and dangerous. This can be what drives expanded inquire for the discovery, determination, and treatment of this infection.

The infection covers a distance extending from 60 to $140 \mathrm{~nm}$, has a spiked protein envelope, and an inherited fabric. The overall structure appears to be similar to that of other Coronaviridae infections. The SARS$\mathrm{CoV}-2$ virus has a 30,000-nucleotide single-stranded positive-sense RNA genome. There are two proteins encoded by the genome, one of which is an RNA-dependent RNA. The infection will stay reasonable and irresistible in mist concentrates for hours and on surfaces of plastic, steel, and cardboard, as well as copper, for days, making vaporized and fomite transmission of SARS-CoV-2 possible. Fig.-1 displays a transmission electron magnifying lens representation of SARS-CoV-2.
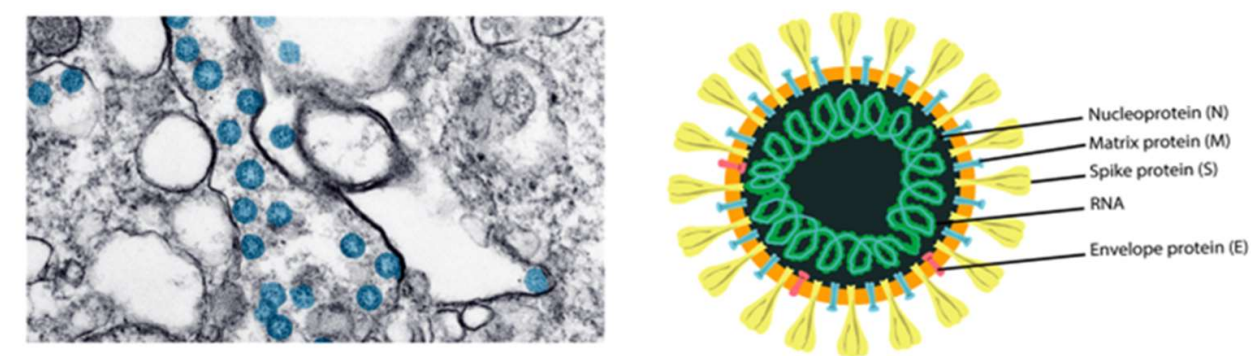

Fig.-1: SARS-CoV-2 Round Viral Particles in a Cell Photographed with a Transmission Electron Magnifying Lens Picture. The Infection has a Blue Tint to it (adjusted from the US Centers for Disease Control). The Basic Viral Proteins are used to represent the Virus's Structure. ${ }^{1}$

Rasayan J. Chem., 14(2), 1006-1010(2021)

http://dx.doi.org/10.31788/ RJC.2021.1426255

This work is licensed under a CC BY 4.0 license. 
RASĀYAN J. Chem.

Vol. 14 | No. 2 |1006-1010| April - June | 2021

Ordinary anti-infectious medicines are known to be compelling, but profoundly subordinate to the appropriateness of structures such as antibodies. The definition requires exact distinguishing proof of pathogenic species, something else this strategy is unreasonable to manage. Natural engineers and researchers have played urgent parts in ensuring the open from viral ailments and proceed to do so nowadays. ${ }^{2}$ A chemist can play a part in avoiding the covid-19, based on information of crystalline structure and chemical computation, as well as nano fabric innovation. ${ }^{3}$ This paper will audit a few cases of nanoHA $\left(\mathrm{Ca}_{10}\left(\mathrm{PO}_{4}\right)_{6}(\mathrm{OH})_{2}\right.$ and its combination that have guarantee potential utilized to battle the covid-19 infection, both utilized for discovery, determination and treatment.

\section{Hydroxyapatite (HA) and Its Ceramics Composite}

HA is a vital biomaterial with therapeutic suggestions in bone and tooth recovery. Reported sources of HA vary from natural ingredients, such as eggshells ${ }^{4}$, avocado fruit peel $^{5}$, and limestone ${ }^{6}$. Due to their association with calcium phosphate materials, several atoms, proteins, polymers, and nanomaterials, both local and biomimetic, have been considered with the intention of understanding and regulating the mineralization process. They have incredible wet, optical, electrical, natural, and mechanical properties due to their higher surface-to-volume proportion. As a result, biomedical innovations such as tissue engineering, bone replacement, pharmaceuticals, dental applications ${ }^{7}$, and controlled drug delivery ${ }^{8}$ impress their interest.

The biomedical applications of biomaterials have been extensively studied. Metals, polymers, and ceramics are examples of these materials. Ceramics, or more specifically bioceramics, may be used as joint or tissue substitutes, coatings for metallic inserts ${ }^{8}$, and as sedate delivery specialists to cancerous cells ${ }^{9}$. The plan of a biomaterial is usually determined by the area in which it is used.

With the flare-up of the Covid-19 infection, numerous endeavors have been made to overcome this issue within the handle of discovery, anticipation, and treatment. This paper tries to survey the conceivable potential of nano-HA to treat illnesses caused by the covid-19 infection. A few of the properties of HA that are considered in its future application are its capacity as an electrically polarized fabric ${ }^{10}$, Piezoelectricity and pyroelectricity, Piezo, and pyroelectricity ${ }^{11}$, porosity, ferroelectricity, and antibacterial ${ }^{12}$.

The open HA structure (Fig.-2) allows modification, for example, by substitution reactions. The substitution can affect biological and mechanical properties. This substitution causes modifications to the parameter lattice and crystallinity, which substantially affects the physiological conditions of the modified HA. Modifications to the hydroxyapatite structure will expand its applications beyond bone-forming agents ${ }^{13-17}$ but also as a microbial agent ${ }^{12,18}$, as a drug delivery system ${ }^{19}$, as a therapeutic agent ${ }^{9}$, as a coating ${ }^{20,21}$ as a biomarker for nanomedical applications ${ }^{22}$ and agricultural application ${ }^{23}$.

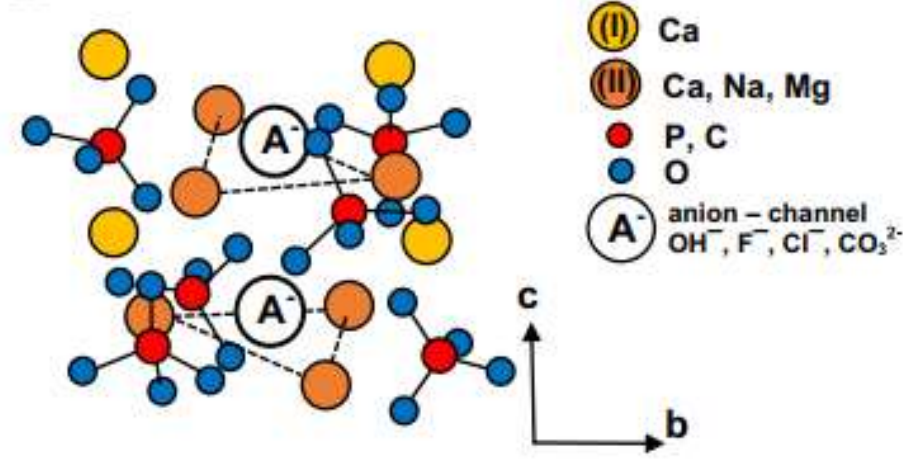

Fig.-2: Visualize the Hydroxyapatite Atomic Structure as a stand-in for bioapatite. ${ }^{24}$

\section{HA as Electrical Material}

$\mathrm{HA}$ is a material with electrical properties, which is associated with the group element (e.g. $\mathrm{CO}_{3}{ }^{2-}, \mathrm{HPO}_{4}{ }^{2-}$, $\mathrm{Na}^{+}, \mathrm{Mg}^{2+}$ ) and trace elements (e.g. $\mathrm{Sr}^{2+}, \mathrm{K}^{+}, \mathrm{Cl}^{-}$and $\mathrm{F}^{-}$), at ppm level. ${ }^{24}$ Sensor-based medical diagnostic equipment relies heavily on electrical material properties. Electrical properties can also be used to learn more about the structure and function of different biological tissues and cells. Living tissue electrical impedance experiments have been successfully interpreted to assess the state of the cell membrane and measure the shape and size of the cells. 
Apatite was synthesized using a variety of natural materials, including eggshells ${ }^{4,25}$, crab shells, and bovine bone. These exchange processes were also commonly used for single crystal synthesis and powder preparation. ${ }^{4}$

\section{Selected DNA Aptamers as Hydroxyapatite Affinity Reagents}

Aptamers have long been used in biosensors to identify or mark small molecules, proteins, cells, and other molecular targets as affinity reagents. HA has been successfully used to recognize DNA aptamers. Analytically labeled, in vitro or in vivo, unknown calcium phosphate may benefit from a selective and competitive HA binder. Present marking reagents are fluorescence-guided in the presence of dissolved calcium cations, but they do not bind or mark the biomaterial. As a result, this reagent is unable to distinguish between amorphous and crystalline compounds. This distinction can be critical in analyzing temporary amorphous minerals seen at the start of the enamel formation stage or detecting calcified plaque arteries in teeth, for example. In such situations, the application of a material-specific DNA aptamer may be beneficial in the potential study of mineralized materials or tissues. ${ }^{10}$ Adopting the HA interaction with DNA aptamer as previously described, this interaction may be the basis of making a covid-19 virus detection tool with a unique amino acid sequence, which can be considered a DNA aptamer.

\section{HA as Antibacterial Material}

HA and its modifications are antibacterial materials, such as graphene oxide HA-cellulose. ${ }^{26}$

\section{Graphene Oxide HA-cellulose}

The nano-HA composite with graphene has the potential to be utilized as a therapeutic cover fabric in avoiding the spread of the Covid-19 infection, due to its antibacterial properties. One of the properties of HA which is in line with the character of graphene is its capacity as a fabric that can halt the development of cancer cells, as a medicate carrier, and a sensor, and as a catalyst. It is coherent that the HA nanocomposite combined with GO is detailed to have uncommon properties. ${ }^{27}$

The synthesized composite film seemed to have good antibacterial activity against both Gram-positive ( $S$. aureus) and Gram-negative (E. coli and Candida albicans) microscopic species. Hence this layer is broadly connected within the biomedical field. Planning Cellulose/HA nanocomposites and proposing it utilize in biomedicine, Ramani and Sastry (2014) had planned fortified cellulose/HA/GO and proposing it as inactive osteoinductive $^{28}$, while Gong and co-workers (2017) had planned GO/HA/Polyamide nanocomposites and proposed their utilization in organic and clinical areas ${ }^{29}$. The later investigation is testing the reactivity of $\mathrm{Ag}$ and HA against cellulose/GO composites. This will be utilized as one of the foremost required cover materials nowadays to diminish the anticipation of the spread of the Covid-19 infection.

The presence of HA can easily be seen, indicating the dispersion of the HA from the fiber to the cellulosic fabric. The strong bond between the HA particles and the cellulose fibers increases their strength. AgNP (Ag-nano particle) creates another layer on the surface of the composite, which is bonded together via metal bonds to form aggregates of different sizes. The composites have shown viable antimicrobial action with a negligible discharge of Ag particles. Indeed, more momentous, the nearness of GO in HA combined with cellulosic filaments enormously diminished Ag particle discharge and AgNP filtering.

\section{Alginate/nano-HA Composites}

HA composites with sodium alginate (ALG) and ciprofloxacin (CIP), namely HA-CIP/ALG and HA/CIPALG, showed higher bioactivity, biocompatibility, and bactericidal activity compared to pure HA. Both composites had a high amount of biogenic hydroxyapatite growing on their surface after 30 days in SBF, suggesting strong bioactivity parameters. Furthermore, both composites exhibited high biocompatibility with calvarias mouse osteoblasts during the three-day incubation period; therefore, no side effects were found in the cells examined in vitro. In this test, both the HA-CIP/ALG and HA/CIP-ALG composites showed antibacterial activity against $S$. aureus in this research, despite having varying degrees of activity. ${ }^{12}$ This means that the degree of activity of composite material is highly dependent on its composition. Viruses (SARS-CoV-2 and SARS-CoV-1) can live for a long time on the surface of several materials (aerosols, plastics, stainless steel, iron, and cardboard). On plastics and stainless steel, SARS-CoV-2 is more robust than on copper and cardboard. ${ }^{30}$ 
RASĀYAN J. Chem.

Vol. 14 | No. 2 |1006-1010| April - June | 2021

As we all know, personal protective equipment (PPE) is needed for health care staff caring for COVID-19 patients, which includes face masks or respirators, protective garments, spill safety gowns, gloves, boot covers, and goggles or face filters for eye protection. ${ }^{31}$ Face masks, such as the N95 aspirator, must fit snugly against a person's face (for example, with a firm rubber band) and can cause significant discomfort or allergic reactions. In reality, one-size-fits-all aspirators do not always match multiple facial profiles, which may lead to leaks or skin injury, posing a safety risk.

Research on the coating with compounds containing HA has also been carried out, including modification of hydroxyapatite induced by polydopamine. The layer structure that results is more compact than pure hydroxyapatite. Due to the synergistic influence of the polydopamine inner layer and the hydroxyapatite outer layer, potentiodynamic polarization and body fluid immersion test simulations indicated that the polydopamine-induced hydroxyapatite layer greatly decreased the corrosion rate. ${ }^{20}$ This discovery is, of course, advantageous and very likely applied to metal-based PPE, especially for magnesium alloys ${ }^{20}$ and titanium implants ${ }^{32}$.

\section{CONCLUSION}

Nano-HA can be used as a biocomposite, a scaffold for newly grown bone tissue, biosensors, antimicrobial materials, and coating materials because of its magnetic, ferroelectric, piezoelectric, and porosity properties. Furthermore, they can be supplemented by ions that are usually absent in bioapatite, such as $\mathrm{Ag}^{+}, \mathrm{Mn}^{2+}$, and $\mathrm{Ti}^{4+}$, which can enhance their antibacterial, mechanical, and corrosion resistance. However, to get to the application stage and to commercialize it for handling medical problems such as handling the Covid-19 virus, intensive research is needed that involves many scientists, such as chemists, material scientists, biologists, biologists, and doctors.

\section{ACKNOWLEDGMENT}

The authors would like to thank the financial support from the Riset Data Pustaka dan Daring (RDPD) Grant of Universitas Padjadjaran (Grant No. 1733/UN6.3.1/LT/2020).

\section{REFERENCES}

1. B. Udugama, P. Kadhiresan, H. N. Kozlowski, A. Malekjahani, M. Osborne, V. Y. C. Li, H. Chen, S. Mubareka, J. B. Gubbay, and W. C. W. Chan, American Chemical Society Nano, 14(4), 3822(2020), DOI: $10.1021 /$ acsnano.0c02624

2. K. R. Wigginton and A. B. Boehm, Environmental Science \& Technology, 54(7), 3736(2020), DOI: $10.1021 /$ acs.est.0c01476

3. L. Kiessling, P. Chen, J. Wang, and J. P. Li, American Chemical Society Chemical Biology, 15(4), 799(2020), DOI: 10.1021/acschembio.0c00175

4. A. R. Noviyanti, N. Akbar, Y. Deawati, E. E. Ernawati, Y. T. Malik, R. P. Fauzia, and Risdiana, Heliyon, 6(4), e03655(2020), DOI:10.1016/j.heliyon.2020.e03655

5. S. Pawar, T. Theodore, and P. G. Hiremath, RASĀYAN Journal of Chemistry, 12(4), 1964(2019), DOI: $10.31788 /$ RJC.2019.1245425

6. N. Jamarun, Z. Azharman, S. Arief, T. P. Sari, A. Asril, and S. Elfina, RASĀYAN Journal of Chemistry. 8(1), 133(2015)

7. Charlena, A. Bikharudin, S. T. Wahyudi, and Erizal, RASĀYAN Journal of Chemistry, 10(3), 766(2017), DOI:10.7324/RJC.2017.1031768

8. A. A. Shaly, G. H. Priya, and J. M. Linet, Physica B: Condensed Matter, 590, 412223(2020), DOI: $10.1016 /$ j.physb.2020.412223

9. T. P. Ribeiro, F. J. Monteiro, and M. S. Laranjeira, Ceramics International, 46(10), 16590(2020), DOI: $10.1016 /$ j.ceramint.2020.03.231

10. A. Das and D. Pamu, Materials Science and Engineering: C, 101, 539(2019), DOI: 10.1016/j.msec.2019.03.077

11. R. Rodriguez, D. Rangel, G. Fonseca, M. Gonzalez, and S. Vargas, Results in Physics, 6, 925(2016), DOI: $10.1016 /$ j.rinp.2016.11.005

12. L. Benedini, J. Laiuppa, G. Santillán, M. Baldini, and P. Messina, Materials Science and Engineering: C, 115, 111101(2020), DOI:10.1016/j.msec.2020.111101 
RASĀYAN J. Chem.

Vol. 14 | No. 2 |1006-1010| April - June | 2021

13. S. Yadav, P. Singh, and R. Pyare, Ceramics International, 46(8), 10442(2020), DOI: $10.1016 /$ j.ceramint.2020.01.043

14. A. H. Dewi and I. D. Ana, Heliyon, 4(10), e00884(2018), DOI:10.1016/j.heliyon.2018.e00884

15. J. Prakash, D. Prema, K. S. Venkataprasanna, K. Balagangadharan, N. Selvamurugan, and G. D. Venkatasubbu, International Journal of Biological Macromolecules, 154, 62(2020), DOI: 10.1016/j.jibiomac.2020.03.095

16. A. R. Noviyanti, I. Rahayu, R. P. Fauzia, and Risdiana, Arabian Journal of Chemistry, 14(4), 133032(2021), DOI:10.1016/j.arabjc.2021.103032

17. S. E. Cahyaningrum, N. Herdyastuti, D. Supangat, B. Devina, and M. Kurniasari, RASĀYAN Jounal of Chemistry, 11(2), 488(2018), DOI:10.31788/RJC.2018.1121916

18. J. Wang, X. Gong, J. Hai, and T. Li, Vacuum, 152, 132(2018), DOI:10.1016/j.vacuum.2018.03.015

19. K. Lin, Y. Zhou, Y. Zhou, H. Qu, F. Chen, Y. Zhua, and J. Chang, Journal of Materials Chemistry, 21, 16558(2011), DOI:10.1039/c1jm12514a

20. Z. Zhou, B. Zheng, Y. Gu, C. Shen, J. Wen, Z. Meng, S. Chen, J. Ou, and A. Qin, Surfaces and Interfaces, 19, 100501(2020), DOI:10.1016/j.surfin.2020.100501

21. R. I. M. Asri, W. S. W. Harun, M. A. Hassan, S. A. C. Ghani, and Z. Buyong, Journal of the Mechanical Behavior of Biomedical Materials, 57, 95(2016), DOI:10.1016/j.jmbbm.2015.11S.031

22. E. Duffy, J. Florek, S. Colon and A. E. Gerdon, Analytica Chimica Acta, 1110, 115(2020), DOI: 10.1016/j.aca.2020.03.029

23. K. Rop, D. Mbui, G. N. Karuku, I. Michira, and N. Njomo, Results in Chemistry, 2, 100020(2020), DOI: $10.1016 /$ j.rechem.2019.100020

24. M. Šupová, Ceramics International, 41(8), 9203(2015), DOI:10.1016/j.ceramint.2015.03.316

25. N. Mohan, R. Palangadan, F. B. Fernandez, and H. Varma, Materials Science and Engineering: C, 92, 329(2018), DOI: 10.1016/j.msec.2018.06.064

26. Z. Pasandideh, M. Tajabadi, J. Javadpour, and S.M. Mirkazemi, Ceramics International, 46(10), 16104(2020), DOI:10.1016/j.ceramint.2020.03.163

27. I. S. Yahia, M. Shkir, and S. M. A. S. Keshk, Results in Physics, 16, 102990(2020), DOI: 10.1016/j.rinp.2020.102990

28. D. Ramani and T. P. Sastry, Cellulose, 21, 3585(2014), DOI:10.1007/s10570-014-0313-4

29. M. Gong, Q. Zhao, L. Dai, Y. Li, and T. Jiang, Journal of Asian Ceramic Societies, 5(2), 160(2017), DOI: 10.1016/j.jascer.2017.04.001

30. N. v. Doremalen, T. Bushmaker, D. H. Morris, M. G. Holbrook, A. Gamble, B. N. Williamson, A. Tamin, J. L. Harcourt, N. J. Thornburg, S. I. Gerber, J. O. Lloyd-Smith, E. d. Wit, and V. J. Munster, The New England Journal of Medicine, 382(16), 1564(2020), DOI:10.1056/NEJMc2004973

31. H. Huang, C. Fan, M. Li, H. Nie, F. Wang, H. Wang, R. Wang, J. Xia, X. Zheng, X. Zuo, and J. Huang, American Chemical Society Nano, 14(4), 3747(2020), DOI:10.1021/acsnano.0c02618

32. A. Bral and M. Y. Mommaerts, Journal of Cranio-Maxillofacial Surgery, 44(4), 400(2016), DOI: $10.1016 / j . j c m s .2015 .12 .004$

[RJC-6255/2020] 